\title{
Comparison of different configurations of the solar and wind power supply system with energy storage using Matlab
}

\author{
Damian Głuchy ${ }^{1}$, Tomasz Jarmuda ${ }^{1, *}$, Andrzej Tomczewski ${ }^{1}$ \\ ${ }^{1}$ Poznan University of Technology, Piotrowo 3A, 60-965 Poznan, Poland
}

\begin{abstract}
In the study the hybrid model of the solar and wind power supply system with electrochemical energy storage developed in MATLAB \& SIMULINK and MS Visual Studio environments was presented. Simulation tests of the system with rated power of $60 \mathrm{~kW}$ were conducted in different configurations of connections with the receiver with the set load characteristics. For each configuration of the system the length of periods with no power supply of the receiver was calculated along with the value of the energy consumed and given to the power grid in the case of application of the electrochemical storage and its lack.
\end{abstract}

\section{Introduction}

Generation of electrical energy in the systems using a single wind or solar source has a stochastic character resulting from the randomly changing weather conditions. One of the ways of mitigating a restless character of their operation is the application of hybrid systems with energy storage. Electrochemical storage systems are the most popular among them due to big energy density and simple use.

\section{Modelling of a Hybrid System}

The analysis of operation of the hybrid system requires development of its mathematical and numerical model. It is also significant for the model to combine two characteristics: accuracy relevant for the scientific tests and considerable speed of calculations connected with the use of great number of input data (irradiation time series and wind speed) $[1,2]$.

PV module models (2-diode model), wind turbines (discrete power characteristics) and electrochemical storage system (circuit model with one RC branch) [3, 4] were developed in Matlab and MS Visual Studio environments. Values of instantaneous power supplied from the hybrid source were calculated and included in the load curve using measurement data of irradiation and wind speed from a specific location. On that basis the periods of energy deficit were determined (energy intake from the storage or from the power system) along with the periods of overproduction (storage of energy in the energy storage system or its introduction to network) $[5,6,7,8]$.

\section{Simulation of Hybrid System Operation under Real Load}

The hybrid system with the total power of $60 \mathrm{~kW}$ constructed of PV modules type BVM6612P $310 \mathrm{~W}$ manufactured by Boviet and Excel 10 wind turbines manufactured by Bergey Windpower Company in three configurations was subject to simulation tests (Table 1).

Table 1. Variants of connection configurations of the solar and wind hybrid system with the power of $60 \mathrm{~kW}$.

\begin{tabular}{|c|c|c|c|c|c|c|}
\hline \multirow{2}{*}{ Name } & \multicolumn{2}{|c|}{ Wind turbines section } & \multicolumn{2}{c|}{ PV modules section } \\
\cline { 2 - 7 } & $\begin{array}{c}\text { No. of } \\
\text { elem. }\end{array}$ & $\begin{array}{c}\text { Power } \\
{[\mathrm{kW}]}\end{array}$ & $\begin{array}{c}\text { Section } \\
\text { power } \\
{[\mathrm{kW}]}\end{array}$ & $\begin{array}{c}\text { No. of } \\
\text { elem. }\end{array}$ & $\begin{array}{c}\text { Power } \\
{[\mathrm{W}]}\end{array}$ & $\begin{array}{c}\text { Section } \\
\text { power } \\
{[\mathrm{kW}]}\end{array}$ \\
\hline $\begin{array}{c}\text { PV30 } \\
\text { TW30 }\end{array}$ & 3 & 10.0 & 30.0 & 97 & 310.0 & 30.1 \\
\hline $\begin{array}{c}\text { PV20 } \\
\text { TW40 }\end{array}$ & 2 & 10.0 & 20.0 & 129 & 310.0 & 40.0 \\
\hline $\begin{array}{c}\text { PV40 } \\
\text { TW20 }\end{array}$ & 4 & 10.0 & 40.0 & 65 & 310.0 & 20.2 \\
\hline
\end{tabular}

Load characteristics corresponds to the load curve of the office facility in which the increase in the demand for energy is visible in the afternoon hours. Assuming the identical character of load for the whole year, the annual demand for electrical energy amounts to about $58.9 \mathrm{MWh}$.

Lithium-ion storage with the capacity of $30 \mathrm{kAh}$ was used in the system, which enables accumulation of energy equalling the average 16-hour demand of the implemented load. It was assumed that the storage operates in constant ambient temperature, close to the rated value, while the phenomenon of self-discharge of the cell and the memory effect were disregarded. The developed model of the tested system was presented in Figure 1.

Figure 2 presents the resultant power changes of PV30TW30 variant for the hybrid system (sum of solar and wind section power) and load of 8 January 2011. 


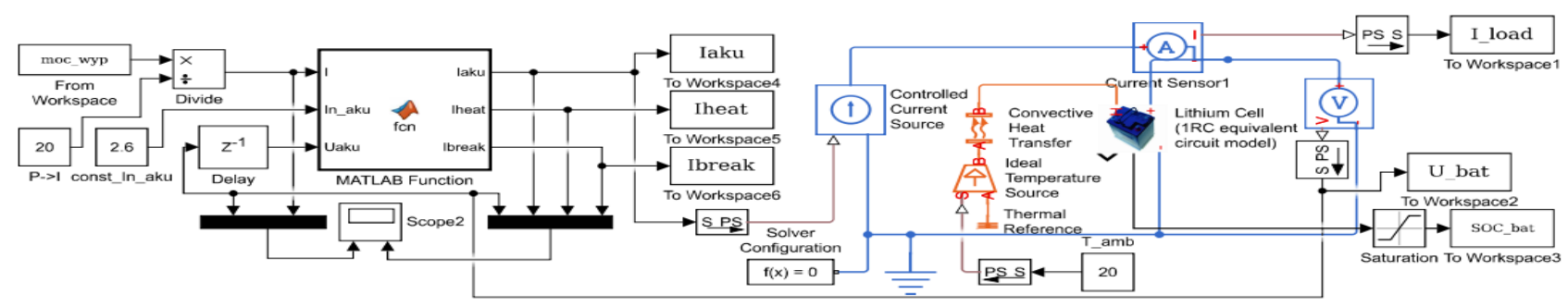

Fig. 1. The MATLAB \& SIMULINK model of the controller and the energy storage cooperating with the hybrid power generation.

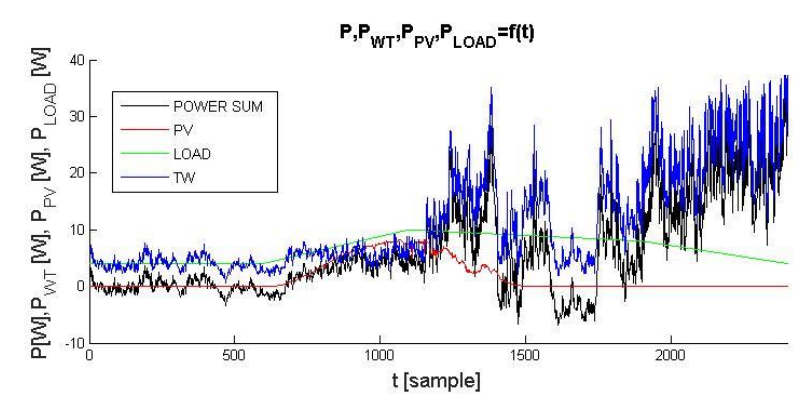

Fig. 2. Power changes: generated, load and resultant for the analysed system for measurement data of 08.01.2011.

Table 2 presents the results of simulation of the operation of the hybrid system conducted for three configurations of its connections. The prepared results cover the annual value: energy generated from wind turbines and photovoltaic modules, energy deficit and time of energy deficit for the system with the switched on energy storage and without the energy storage. The calculations were conducted with reference to the annual demand for electrical energy (58.9 MWh) resulting from the assumed load curve.

Table 2. Specification of generated energy and periods with energy deficit for three configuration variants.

\begin{tabular}{|c|c|c|c|}
\hline & $\begin{array}{c}\text { PV30 } \\
\text { TW30 }\end{array}$ & $\begin{array}{c}\text { PV20 } \\
\text { TW40 }\end{array}$ & $\begin{array}{c}\text { PV40 } \\
\text { TW20 }\end{array}$ \\
\hline Energy WT [MWh] & 38.67 & 51.55 & 25.78 \\
\hline Energy PV [MWh] & 32.23 & 21.60 & 42.87 \\
\hline Energy balance [MWh] & 11.91 & 14.16 & 9.65 \\
\hline $\begin{array}{c}\text { Total energy taken from the grid } \\
\text { without energy storage [MWh] }\end{array}$ & -20.65 & -20.65 & -21.98 \\
\hline $\begin{array}{c}\text { Total energy supplied to the grid } \\
\text { without energy storage [MWh] }\end{array}$ & 32.56 & 34.81 & 31.63 \\
\hline $\begin{array}{c}\text { Total period of energy deficit } \\
\text { without energy storage [days] }\end{array}$ & 218.60 & 218.60 & 228.60 \\
\hline $\begin{array}{c}\text { Total energy taken from the grid } \\
\text { with energy storage [MWh] }\end{array}$ & -9.02 & -10.63 & -9.15 \\
\hline $\begin{array}{c}\text { Total energy supplied to the grid } \\
\text { with energy storage [MWh] }\end{array}$ & 19.26 & 25.03 & 18.94 \\
\hline $\begin{array}{c}\text { Total period of energy deficit } \\
\text { with energy storage [days] }\end{array}$ & 85.80 & 103.79 & 86.89 \\
\hline
\end{tabular}

\section{Summary}

On the basis of the results of the conducted simulations it may be found that the application of the hybrid system increases the stability and reliability of electrical energy production compared to the wind and solar systems that work independently. In the considered example, depending on the selected variant, the annual demand of 58.9 MWh was covered from the system with the power of $60 \mathrm{~kW}$ (without storage), obtaining the energy overproduction within the scope from 16 to $24 \%$. However, these values do not reflect local energy deficits that last for as long as 220 days during the year. At the same time, during the year it was necessary to supply almost $35 \mathrm{MWh}$ to the power grid during the periods of overproduction and take $20 \mathrm{MWh}$ from the grid during the energy deficit periods for PV20TW40 variant.

Adding the energy storage allowed to improve the properties of operation of the hybrid system. In the considered case this allowed to shorten total period of energy deficit to 85 days. The use of energy storage allowed to reduce the amount of energy supplied to the power grid by $28 \%(25 \mathrm{MWh})$ and taken from the grid by $48 \%(10 \mathrm{MWh})$ in the worst from the considered configurations, that is PV20TW30. In the best case (PV40TW20), the energy balance was improved by $40 \%$ (9 MWh) and 58\% (19 MWh), respectively.

From the conducted simulations it clearly follows that the use of energy storage for hybrid systems results in reduction of energy flow between the wind and solar sources, receiver and the power grid. This enables better local use of energy from renewable energy sources, with simultaneous shedding of the power grid, which is connected with the increase in the installation costs.

\section{References}

1. A. Tomczewski, The Scientific World Journal, Article ID 643769, 16 pages (2014)

2. D. Głuchy, L. Kasprzyk, Prz. Elektrotech. 12, 99102 (2017)

3. G. Trzmiel, Eksploat. Niezawodn. 19 (4), 516-521 (2017)

4. L. Kasprzyk, A. Tomczewski, K. Bednarek, A. Bugała, International Conference Energy, Environment and Material Systems, 91-92 (2017)

5. L. Kasprzyk, Eksploat. Niezawodn. 19 (2), 229-236 (2017)

6. S. S. Singh, E. Fernandez, Energy 143, 719-731 (2018)

7. U. Akram, M. Khalid, S. Shafiq, IET Renewable Power Generation 12 (1), 72-80 (2018)

8. U. Westerhoff, K. Kurbach, F. Lienesch, M. Kurrat, Energy Technology 4, 1620-1630 (2016)

\footnotetext{
Corresponding author: tomasz.jarmuda@put.poznan.pl
} 